AperTO - Archivio Istituzionale Open Access dell'Università di Torino

\title{
Ultra-Fast Silicon Detectors for 4D tracking
}

\section{This is the author's manuscript}

Original Citation:

Availability:

This version is available http://hdl.handle.net/2318/1732198

since 2020-10-24T16:11:49Z

Published version:

DOI:10.1088/1748-0221/12/02/C02072

Terms of use:

Open Access

Anyone can freely access the full text of works made available as "Open Access". Works made available under a Creative Commons license can be used according to the terms and conditions of said license. Use of all other works requires consent of the right holder (author or publisher) if not exempted from copyright protection by the applicable law. 
Ultra-Fast Silicon Detectors for 4D tracking

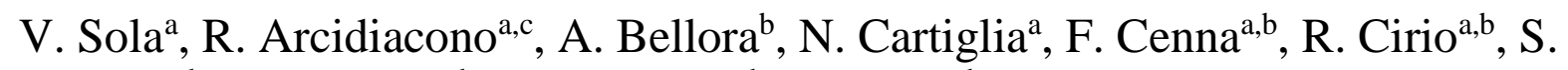
Durando $^{\mathrm{b}}$, M. Ferrero ${ }^{\mathrm{a}, \mathrm{b}}$, Z. Galloway ${ }^{\mathrm{d}}$, B. Gruey ${ }^{\mathrm{d}}$

We review the progress toward the development of a novel type of silicon detectors suited for tracking with a picosecond timing resolution, the so called Ultra-Fast Silicon Detectors. The goal is to create a new family of particle detectors merging excellent position and timing resolution with $\mathrm{GHz}$ counting capabilities, very low material budget, radiation resistance, fine granularity, low power, insensitivity to magnetic field, and affordability. We aim to achieve concurrent precisions of $\sim 10 \mathrm{ps}$ and $\sim 10 \mu \mathrm{m}$ with a 50 $\mu \mathrm{m}$ thick sensor. Ultra-Fast Silicon Detectors are based on the concept of Low-Gain Avalanche Detectors, which are silicon detectors with an internal multiplication mechanism so that they generate a signal which is factor $\sim 10$ larger than standard silicon detectors. 